\title{
Income and wealth
}

Sonia Carrera and Jen Beaumont

\author{
Edition No.: $\quad$ Social Trends 41 \\ Editor: Jen Beaumont \\ Office for National Statistics
}

\section{Social Trends 41}


ISSN 2040-1620

\section{A National Statistics publication}

National Statistics are produced to high professional standards set out in the Code of Practice for Official Statistics. They are produced free from political influence.

\section{About us}

\section{The Office for National Statistics}

The Office for National Statistics (ONS) is the executive office of the UK Statistics Authority, a non-ministerial department which reports directly to Parliament. ONS is the UK government's single largest statistical producer. It compiles information about the UK's society and economy, and provides the evidence-base for policy and decision-making, the allocation of resources, and public accountability. The DirectorGeneral of ONS reports directly to the National Statistician who is the Authority's Chief Executive and the Head of the Government Statistical Service.

\section{The Government Statistical Service}

The Government Statistical Service (GSS) is a network of professional statisticians and their staff operating both within the Office for National Statistics and across more than 30 other government departments and agencies.

\section{Contacts}

\section{This publication}

For information about the content of this publication, contact Jen Beaumont

Tel: 01633651622

Email: social.trends@ons.gsi.gov.uk

\section{Other customer enquiries}

ONS Customer Contact Centre

Tel: 08456013034

International: +44(0)8456013034

Minicom: 01633815044

Email: info@statistics.gsi.gov.uk

Fax: 01633652747

Post: Room 1.101, Government Buildings, Cardiff Road, Newport, South Wales NP10 8XG

www.ons.gov.uk

\section{Media enquiries}

Tel: 08456041858

Email: press.office@ons.gsi.gov.uk

\section{Copyright and reproduction}

(C) Crown copyright 2010

You may re-use this information (not including logos) free of charge in any format or medium, under the terms of the Open Government Licence.

To view this licence, go to:

http://www.nationalarchives.gov.uk/doc/opengovernment-licence/ or write to the Information Policy Team, The National Archives, Kew, London TW9 4DU email: psi@nationalarchives.gsi.gov.uk. 
The United Kingdom has experienced many changes to both its economy and society, and these two aspects are related. In this analysis, long and short-term trends in a number of aspects of household and individual economic circumstances are examined in relation to economic activity levels in the UK. Living standards depend on the level of economic activity and on the redistribution of economic resources within society as a whole, and have a major influence on social well-being. Income and wealth are generally analysed at the level of either the family or the household, because these are the units across which income and expenditure are considered to be pooled, so that the income of the family or household can be regarded as representative of the standard of living of each person living in it. However, for some purposes such as the analysis of income from employment, income is analysed for individuals.

\section{Key Points:}

\section{Trends in the economy and household income}

- During the recent recession (2008 to 2009) GDP per head decreased by 5.5 per cent while real household disposable income per head increased by 1.2 per cent

- The decrease in GDP per head between 2008 and 2009 was the largest annual percentage decrease in any year since 1949

- Unlike the 1970s and 1980s, real household disposable income per head grew almost continuously through the 1990 s and 2000 s, irrespective of recessions

\section{Sources of household income}

- On average, from 2006/07 to 2008/09 an estimated 73 per cent of household income was derived from wages, salaries and self-employed earnings

\section{Household income distribution}

- Pensioner households and lone parent households are more likely to be in the lower end of the income distribution

- Couples without children are more likely to be at the higher end of the income distribution

- In 2008/09 an estimated 18 per cent of individuals in the UK were from households with low income - below 60 per cent of contemporary median income. This is virtually unchanged since $1998 / 99$

- In 2008/09 a higher proportion of pensioners and children lived in households with low income, although both percentages had decreased since 1998/99

- People living in households where income was below $£ 20,000$ per annum were considerably more likely to perceive their household financial situation as bad or very bad in 2009 than those living in households with higher incomes 


\section{Earnings growth}

- Between 2008 and 2009 earnings growth was larger for part-time employees and smallest for male full-time employees

- Between 1998 and 2009 earnings grew on average at a faster rate than inflation

\section{Household wealth}

- Household net wealth more than doubled in real terms between 1987 and 2009, from £56,000 to $£ 117,000$ in $2008 / 09$ prices

- Household net wealth was lower in 2009 than in 2007 largely because of the decrease in total property assets as a result of the fall in house prices during the 2008-2009 recession

\section{Household savings}

- Household saving as a percentage of household income increased from 2.0 per cent to 7.0 per cent between 2008 and 2009. This increase followed a decrease in 2008 to the lowest recorded value since 1970

\section{Taxes}

- H M Revenue \& Customs (HMRC) estimated that income tax paid in 2010/11 would be 18.3 per cent of all income on average

- For those earning incomes between $£ 6,475$ and $£ 7,499$ income tax would be 1.3 per cent of overall income, and for those with an income of $£ 1$ million and over 44.4 per cent

- Indirect taxes, such as Value Added Tax, duties and levies, form a larger percentage of the disposable income of those who earn less, even though they may also spend less 


\section{Trends in the economy and household income}

Gross domestic product (GDP) is the total value of output in the UK and is used to measure change in economic activity. Over long periods of time, change in GDP can be greatly affected by change in the size of the population. Therefore, GDP per head is the preferred measure for comparison over time. Between 1970 and 2009, GDP per head in the UK more than doubled in real terms although the annual rate of change varied over the period (Figure 1).

\section{Figure 1 Real household disposable income per head ${ }^{1}$ and gross GDP per head ${ }^{2}$}

United Kingdom

Index numbers $(1970=100)$

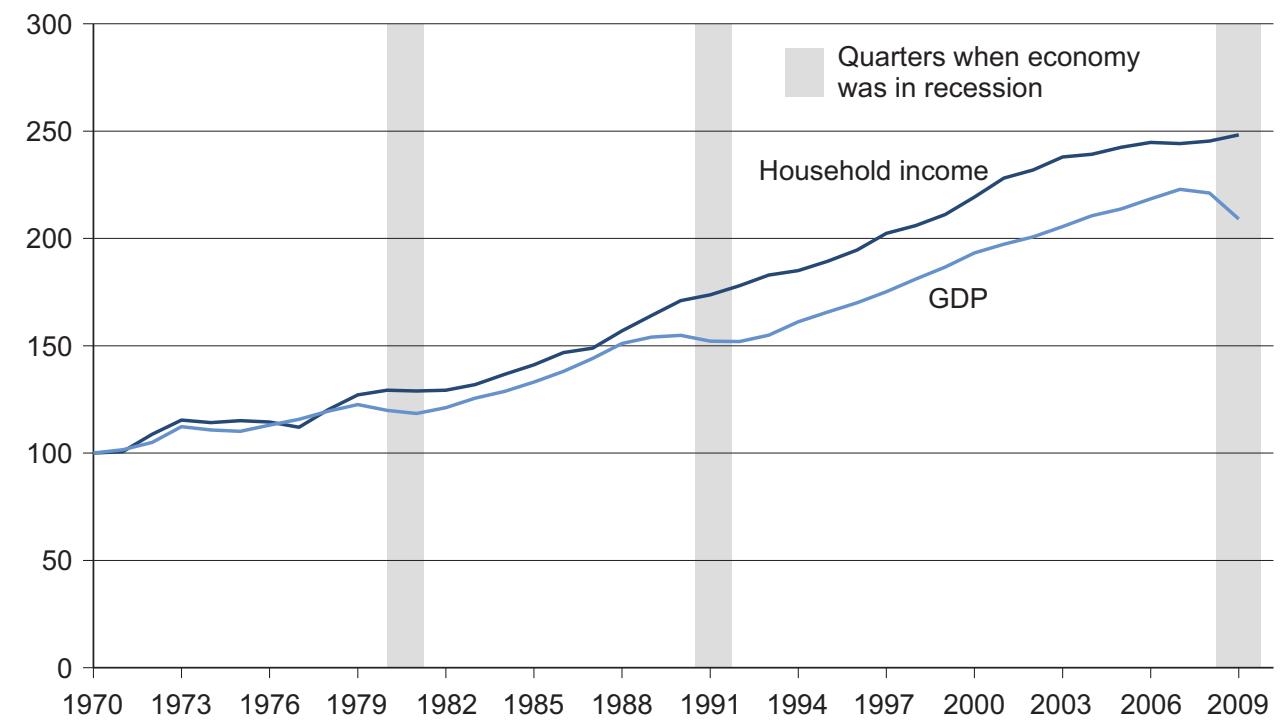

1 Adjusted to real terms using the expenditure deflator for the household sector.

2 Adjusted to real terms using the GDP deflator.

Source: Office for National Statistics

There was a period of continuous growth in GDP per head from 1992 until 2007, albeit with some year-on-year variation, followed by a slight decrease in 2008 at the start of the most recent recession. The generally accepted definition of recession is that GDP falls in at least two consecutive quarters. In Figure 1, which shows annual figures, the recessions of the 1980s, the 1990s and most recently between 2008 and 2009 are indicated by shading. Between 2008 and 2009, GDP per head dropped sharply by 5.5 per cent, falling to just below its 2004 level. This is the largest annual percentage decrease in GDP per head in any year since 1949.

When assessing material living standards within a society another important consideration is the level of household' income (Chiripanhura, 2010). Over the period 1970 to 2009 in the UK, GDP and real household disposable income per head grew on average by 1.9 and 2.4 per cent per year respectively. In the 1970s real household disposable income per head tended to increase more than GDP per head in times of economic growth, and decrease more than GDP per head in times of recession. This relationship changes in the 1980s, with real household disposable income per 
head continuing to rise during the recession in the early 1990s, albeit at a slower rate than the preceding few years. Since then, real household disposable income per head growth was more variable than growth in GDP per head up to 2001, varying between 1.1 per cent and 4.0 per cent. Growth slowed to 0.5 per cent in 2008 and 2009. This recent growth in real household disposable income per head during the recession is in part due to the fall in interest paid on mortgages and the fall in taxes and increase in social benefits.

\section{Table $1 \quad$ Perceptions of the current economic climate ${ }^{1}$ by income grouping, 2009²}

United Kingdom

\begin{tabular}{rrrrrrr} 
& & & Percentages \\
\hline & Less than & $£ 20,000-$ & $£ 40,000-$ & $£ 60,000-$ & $£ 100,000$ & All \\
$£ 20,000$ & $£ 39,999$ & $£ 59,999$ & $£ 99,999$ & and over individuals \\
\hline
\end{tabular}

The economic situation in the world

$\begin{array}{lrrrrrr}\text { Good or very good } & 6 & 3 & 2 & 1 & 0 & 4 \\ \text { Neither good or bad } & 17 & 18 & 12 & 8 & 8 & 16 \\ \text { Bad or very bad } & 77 & 79 & 85 & 91 & 92 & 80\end{array}$

The economic situation in the UK

$\begin{array}{lrrrrrr}\text { Good or very good } & 8 & 5 & 4 & 4 & 0 & 6 \\ \text { Neither good or bad } & 17 & 15 & 13 & 4 & 11 & 15 \\ \text { Bad or very bad } & 76 & 80 & 83 & 92 & 89 & 80\end{array}$

\section{The financial situation in your household}

\begin{tabular}{lllllll} 
Good or very good & 28 & 44 & 54 & 64 & 63 & 40 \\
Neither good or bad & 47 & 42 & 35 & 36 & 34 & 43 \\
Bad or very bad & 25 & 14 & 11 & 1 & 3 & 18 \\
\hline
\end{tabular}

1 Respondents aged 16 and over were asked 'How would you judge the current situation in each of the following?' regarding the aspects shown. Results are based only on those respondents who, in a separate question, provided information on their income.

2 Data were collected in February to March.

Source: 2009 Survey of Public Attitudes and Behaviours towards the Environment, Department for Environment, Food and Rural Affairs

As well as looking at objective measures of the economy and household income, subjective measures that look at people's views on the economic situation are also useful. Peoples' reported perception of the economic situation at an international, national and household level tends to vary by their actual standards of living. In 2009, 80 per cent of people in the UK thought that the current economic situation both in the world and the UK was bad or very bad (Table 1). Those with higher 
incomes were more likely to judge the economic situation as bad or very bad. However, in the same survey 18 per cent of respondents thought that the financial situation in their own household was bad or very bad with those with lower incomes more likely to report that the household situation was bad ( 25 per cent of those with incomes less than $£ 20,000$ compared with 3 per cent of those with incomes of $£ 100,000$ and over).

\section{Sources of household income}

On average, for $2006 / 07$ to $2008 / 09$, an estimated 73 per cent of all household income was derived from wages, salaries and self-employed earnings, 13 per cent came from state retirement and other pensions, 9 per cent from benefits and tax credits and 3 per cent from investments. The relative contribution of different sources of household income varies by characteristics such as household composition, region, and the occupation, age and ethnic group of the household reference personi".

\section{Table 2 Sources of total weekly household income: by ethnic group of household reference person, 2006/07-2008/09}

United Kingdom

Percentages

\begin{tabular}{|c|c|c|c|c|c|c|c|c|c|c|}
\hline & $\begin{array}{l}\text { Wages } \\
\text { and e } \\
\text { salaries }\end{array}$ & $\begin{array}{l}\text { Self- } \\
\text { mployed } \\
\text { income Investmen }\end{array}$ & & $\begin{array}{l}\text { Tax } \\
\text { credits }\end{array}$ & $\begin{array}{r}\text { State } \\
\text { retirement } \\
\text { pension }\end{array}$ & $\begin{array}{r}\text { Other } \\
\text { pensions }\end{array}$ & & $\begin{array}{c}\text { Social } \\
\text { security } \\
\text { disability s } \\
\text { benefits b }\end{array}$ & $\begin{array}{l}\text { Other } \\
\text { social } \\
\text { ecurity } \\
\text { enefits s }\end{array}$ & $\begin{array}{l}\text { Other } \\
\text { ources }\end{array}$ \\
\hline White & 64 & 9 & 3 & 1 & 7 & 7 & & 2 & 5 & 2 \\
\hline Mixed & 71 & 8 & 1 & 2 & 2 & 2 & & 1 & 8 & 4 \\
\hline Asian or Asian British & 70 & 9 & 1 & 4 & 2 & 2 & & 1 & 7 & 4 \\
\hline Indian & 74 & 9 & 1 & 1 & 2 & 2 & & 1 & 4 & 4 \\
\hline $\begin{array}{l}\text { Pakistani and } \\
\text { Bangladeshi }\end{array}$ & 56 & 10 & 1 & 10 & 4 & 1 & & 2 & 13 & 4 \\
\hline Black or Black British & 69 & 7 & 0 & 3 & 3 & 1 & & 1 & 10 & 4 \\
\hline Black Caribbean & 70 & 5 & 1 & 3 & 5 & 2 & & 2 & 10 & 2 \\
\hline Black non-Caribbean & 69 & 8 & 0 & 4 & 1 & 1 & & 1 & 11 & 5 \\
\hline $\begin{array}{l}\text { Chinese or other ethnic } \\
\text { group }\end{array}$ & 70 & 8 & 1 & 2 & 2 & 3 & & 1 & 5 & 7 \\
\hline All households & 64 & 9 & 3 & 2 & 6 & 7 & & 2 & 5 & 2 \\
\hline
\end{tabular}

1 May include income support or pension credit.

Source: Family Resources Survey, (DWP, 2010a)

Averaged over the period 2006/07 and 2008/09, the composition of income for households with a reference person belonging to the White ethnic group was very similar to the overall average (Table 2). However, wages and salaries represented a higher proportion of total income for households with a reference person belonging to the Mixed, Indian, Black or Black British, and 
Chinese or other groups. Households with a reference person in the Pakistani and Bangladeshi group and the Black or Black British group derived a higher than average proportion of their income from social security benefits - other than those for disability. Households where the household reference person was from any of the ethnic groups other than White derived a smaller proportion of their income from state retirement and other pensions. This could in part be because lower proportions of people with an ethnic background other than White are in older age groups compared with the White ethnic group, resulting in lower dependence on pensions (ONS, 2009a).

\section{Household income distribution}

Various sources of income differ in importance for different types of households, and levels of earnings vary between individuals. The result is an uneven distribution of total income between households. However, this inequality is reduced to some extent by the deduction of taxes and social contributions, and their subsequent redistribution to the households in the form of benefits from the government. For this reason disposable income is usually used in analysis of household income distribution. Disposable income is also adjusted for household size and composition. This takes into account that to achieve a comparable standard of living a household of, say, three adults will need a higher disposable income than a single person living alone. This adjustment is known as equivalisation $n^{\text {iii. }}$.

\section{Figure 2 Distribution of real ${ }^{1}$ household disposable income ${ }^{2}$}

United Kingdom/Great Britain ${ }^{3}$

$£$ per week at 2008/09 prices

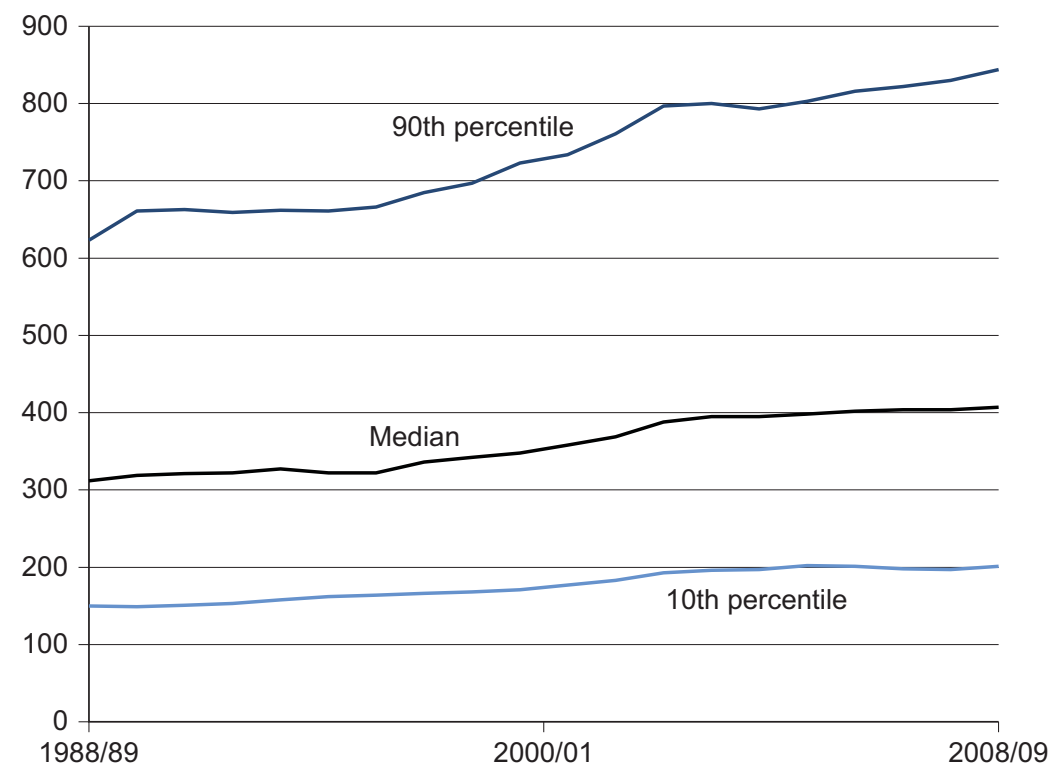

1 Adjusted to 2008/09 prices using the retail prices index less council tax/domestic rates.

2 Equivalised household disposable income before deduction of housing costs, using OECD equivalisation scale.

3 Data for 1994/95 to 2001/02 are for Great Britain only.

Source: Department for Work and Pensions (DWP) 
Figure 2 shows disposable income in pounds per week, before deduction of housing costs, at the median, the 10th percentile (the income of one in ten of the population is below this level) and the 90th percentile (the income of one in ten of the population is above this level) for years between $1988 / 89$ and $2008 / 09$ at $2008 / 09$ prices. Throughout this time period the level of income inequality remained fairly stable. Income at the 90th percentile was more than 4 times the income at the 10th percentile, both in 1988/89 and 2008/09.

\section{Figure 3 Distribution of weekly household disposable income, ${ }^{1}$ 2008/09}

United Kingdom

Millions of individuals

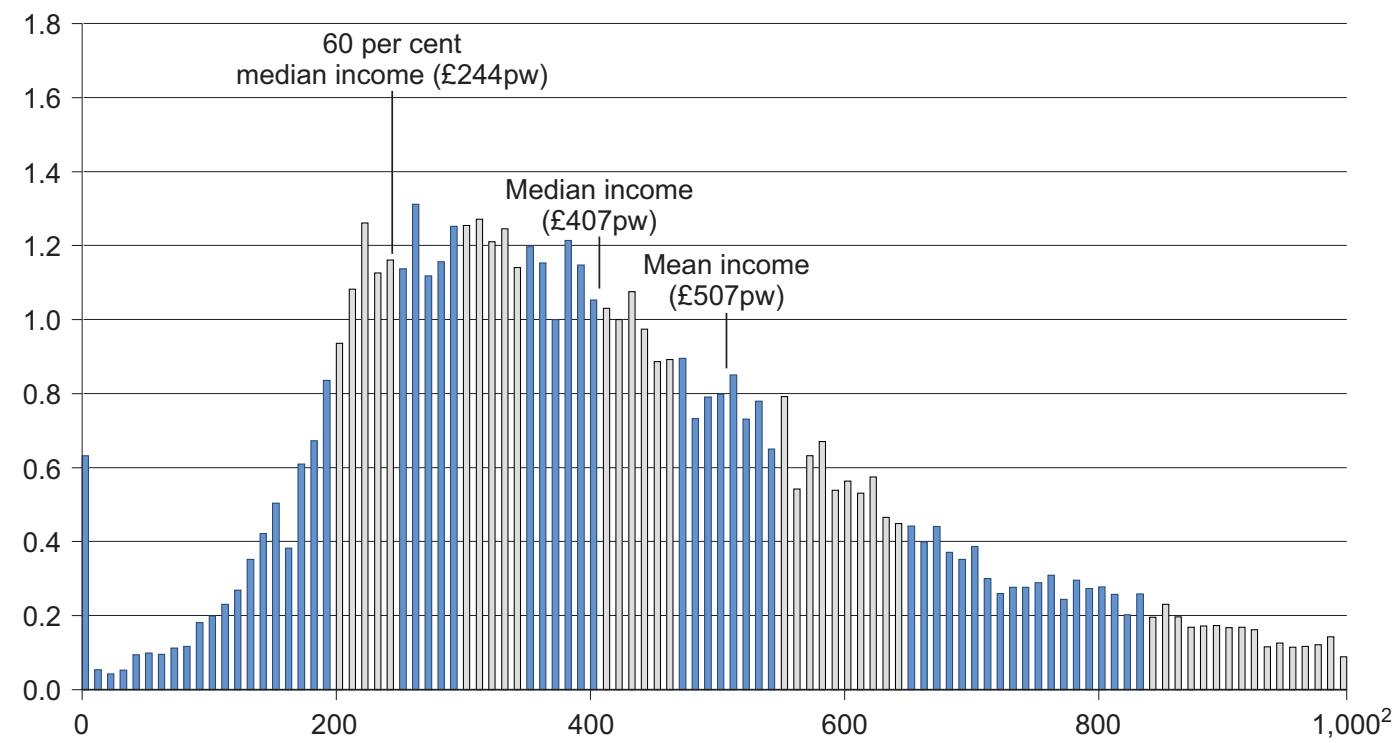

1 Equivalised household disposable income before deduction of housing costs (in $£ 10$ bands), using OECD equivalisation scale. The $£ 10$ bands are grouped into decile groups in alternating colours.

2 There were also an additional 3.6 million individuals with income above $£ 1,000$ per week.

Source: DWP (2010b)

Figure 3 shows a more detailed picture of income distribution in the UK for 2008/09. Disposable incomes, before housing cost deduction, are not distributed equally. There is a much greater concentration of people at lower levels of weekly income, with nearly two-thirds of individuals living in households with disposable weekly income lower than the mean. There is a long 'tail' of people at the higher end of the distribution with an estimated 6 per cent of individuals living in households with disposable incomes of $£ 1,000$ per week or more. This results in a much higher mean income per week, $£ 507$, compared with the median of $£ 407$. 


\section{Table 3 Distribution of household disposable income ${ }^{1}$ by household type, 2008/09}

United Kingdom

Percentages

\begin{tabular}{lrrrrrr}
\hline & Bottom fifth & Second fifth & Middle fifth & Fourth fifth & Top fifthAll (millions) \\
\hline Pensioner couple & 20 & 24 & 21 & 18 & 16 & $\mathbf{7 . 9}$ \\
Single pensioner & 27 & 31 & 22 & 14 & $\mathbf{4 . 7}$ & $\mathbf{2 0 . 7}$ \\
Couple with children & 18 & 20 & 22 & 21 & 19 & $\mathbf{1 1}$ \\
Couple without children & 11 & 9 & 16 & 26 & $\mathbf{3}$ & $\mathbf{5 . 0}$ \\
Single with children & 39 & 31 & 18 & 22 & $\mathbf{2 0}$ & $\mathbf{1 0 . 6}$ \\
Single without children & 21 & 18 & 20 & $\mathbf{2 0}$ & $\mathbf{2 0}$ & $\mathbf{6 0 . 3}$ \\
\hline
\end{tabular}

1 Equivalised household disposable income before deduction of housing costs has been used to rank the individuals into quintile groups.

Source: DWP (2010b)

Household type can be related to position within the income distribution (Table 3). During 2008/09 people living in lone parent households and pensioners living alone were more concentrated at the lower end of the income distribution (39 per cent and 27 per cent respectively in the lowest fifth). A higher proportion of couples without children were concentrated at the top of the distribution (38 per cent in the highest fifth). Single people without children and people living in households consisting of couples with children or pensioner couples were more evenly spread across the income distribution. 


\section{Map 1 Gross Disposable Household Income per head: by NUTS 2 area, ${ }^{1} 2008$}

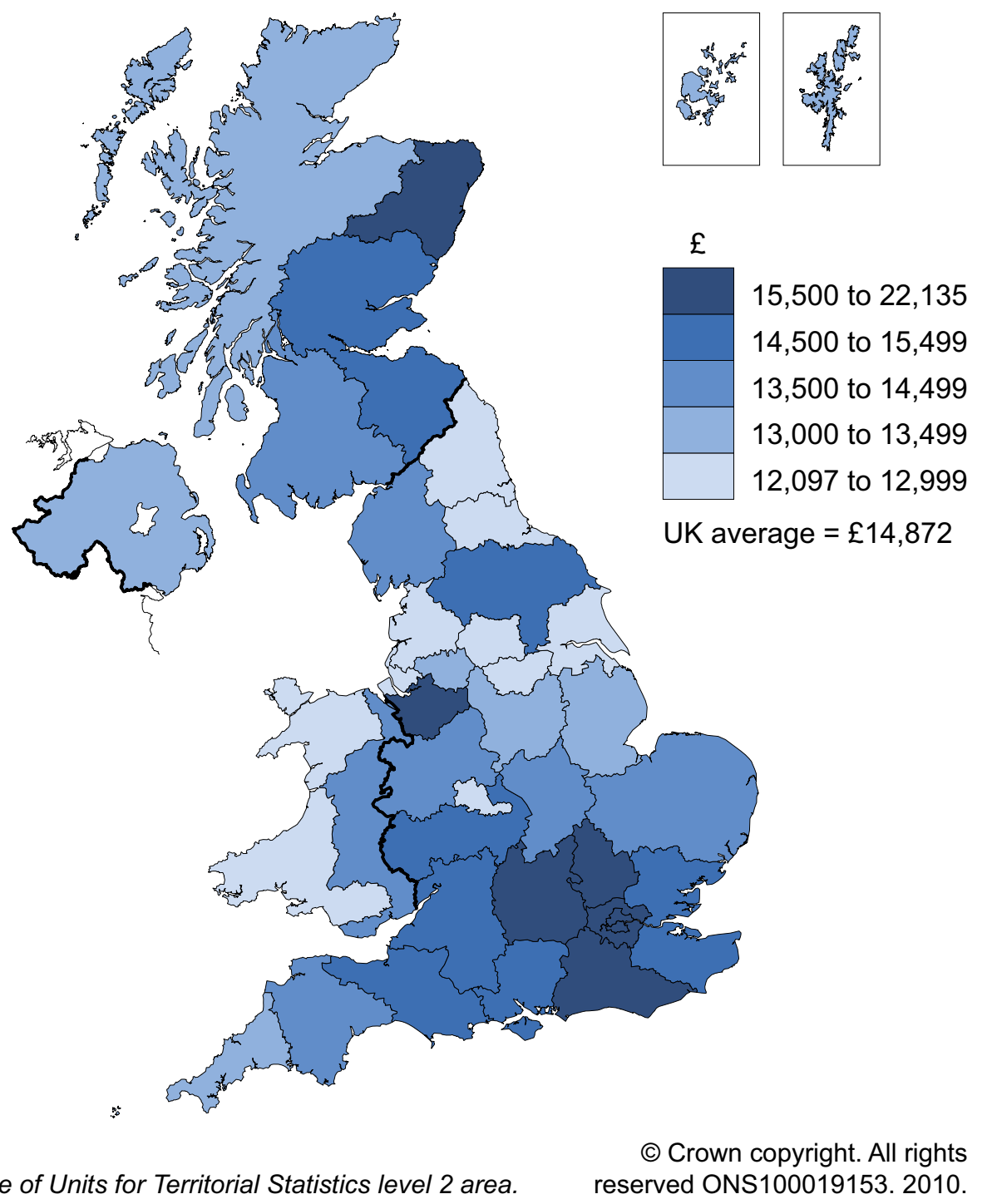

1 Nomenclature of Units for Territorial Statistics level 2 area.

reserved ONS100019153. 2010.

There are also large differences in average gross disposable household income (GDHI) per head in different geographic areas of the UK. Map 1 illustrates how household disposable income per head varied by local areas (NUTS 2 leveliv) in 2008. It shows that GDHI per head was higher in London, the South East and parts of the East of England. Relatively lower incomes were recorded in parts of the West Midlands, the North East and West Wales and the Valleys. The main contribution to GDHI per head comes from compensation of employees, so is strongly influenced by an area's productivity and labour market outcomes. GDHI per head is also influenced by sources of income apart from work such as from property, pensions and social transfers (Oguz et al., 2010). 
The incidence of low income, together with the factors contributing to low income and ways to reduce their effects, have been a focus of attention for government since the first Poor Laws were introduced in the 16th century. Having a low income is associated with being disadvantaged and excluded from many of the opportunities available to the average citizen, and thus affects the level of societal wellbeing.

\section{Figure $4 \quad$ Individuals living in households below 60 per cent of median household disposable income ${ }^{1}$}

United Kingdom

Percentages

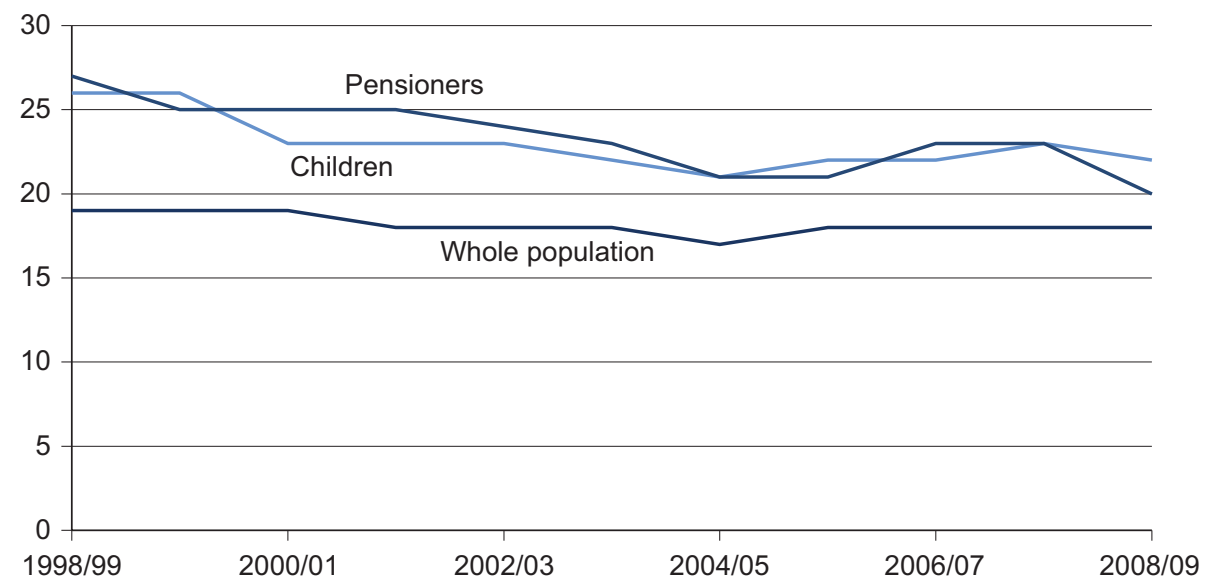

1 Contemporary household disposable income before deduction of housing costs, using OECD equivalisation scale.

Source: DWP (2010b)

The threshold generally used in the UK and other developed countries to define low income is 60 per cent of contemporary equivalised median household disposable income (before deduction of housing costs). In 2008/09 in the UK, 18 per cent of individuals were living in a household with income below this threshold, a proportion similar to that recorded in 1987 (DWP, 2010b). Figure 4 shows that children and pensioners were at higher than average risk of living in a low income household. Between 1998/99 and 2008/09 however, the proportion of children and pensioners in low income households has decreased, from 26 per cent to 22 per cent, and from 27 per cent to 20 per cent, respectively. 


\section{Earnings growth}

\section{Figure $5 \quad$ Earning growth for full-time and part-time employees ${ }^{1}$ and the retail prices index and consumer price index ${ }^{2}$}

United Kingdom

Percentage change over 12 months $^{3}$

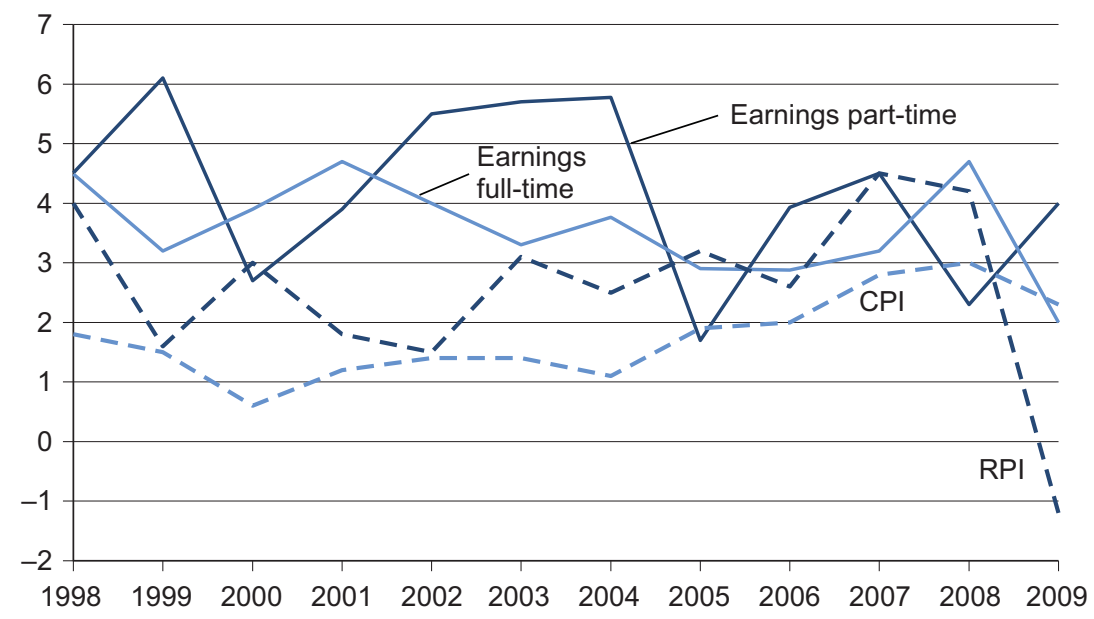

1 Full-time employees on adult rates whose pay for the survey period was unaffected by absence.

2 Further information about $\mathrm{CPI}^{\mathrm{v}}$ and $\mathrm{RPI}^{\mathrm{vi}}$ can be found in notes at the end of this section.

3 Data are at April each year.

Source: Office for National Statistics

Wages and salaries are the largest important components of household and individual incomes in the UK (64 per cent of household income for the years 2006/07 to 2008/09, see Table 2). Between 2008 and 2009 median earnings for both part-time and full-time employees in the UK grew, at 4.0 per cent and 2.0 per cent respectively (Figure 5). Over the same period the consumer price index $\left(\mathrm{CPI}^{\mathrm{v}}\right)$ increased by 2.3 per cent and retail price index $\left(\mathrm{RP}^{\mathrm{vi}}\right)$ decreased by 1.2 per cent.

Between 1998 and 2009 median earnings for part-time employees increased on average by 5.2 per cent per year, while the average growth in earnings for full-time employees was 4.2 per cent. On average, over this period the CPI increased by 1.9 per cent and the RPI by 2.8 per cent per year, meaning that earnings grew at a faster rate than inflation. 


\section{Table $4 \quad$ Gross weekly pay for full-time and part-time employees: by gender, ${ }^{1}$ April 2008 and 2009}

United Kingdom

$£$ per week

Median

\begin{tabular}{|c|c|c|c|}
\hline & 2008 & 2009 & $\begin{array}{r}\text { Percentage } \\
\text { change }\end{array}$ \\
\hline \multicolumn{4}{|l|}{ Male } \\
\hline Full-time & 522.0 & 531.1 & 1.7 \\
\hline Part-time & 136.6 & 143.6 & 5.1 \\
\hline \multicolumn{4}{|l|}{ Female } \\
\hline Full-time & 412.4 & 426.4 & 3.4 \\
\hline Part-time & 149.9 & 155.6 & 3.8 \\
\hline
\end{tabular}

1 Employees on adult rates whose pay for the survey pay-period was not affected by absence.

Source: Annual Survey of Hours and Earnings, ONS (2009c)

The level of earnings in 2008 and 2009 and the change between these two years show differences between the pay for men and women (Table 4). Median weekly earnings for full-time employees were higher for men than women in both years, but weekly earnings for part-time employees were higher for women than men. There was higher growth in median pay for females than males for those in full-time employment and lower growth for women than men for those in part-time work. The lowest growth in median pay was for men in full-time employment.

The difference in earnings growth between men and women can partially be explained by structural changes in employment. According to the Annual Population Survey, between 2008 and 2009 there was a fall in full-time employment rates and an overall increase in part-time employment rates for both men and women. Also men experienced the largest fall in both types of employment. 


\section{Household wealth}

The terms wealth and income are often used interchangeably but they are different. Income represents a flow of resources over a specified period of time received either in cash or in kind, for example, earnings or state benefits. Wealth measures the value of assets owned at a particular point in time. People's ownership of assets contributes to their economic wellbeing as a source of financial security: for example, some assets can be sold to help maintain a stable standard of living when income is falling in real terms. Some forms of wealth can also provide a current income flow, for example, interest on savings.

\section{Figure $6 \quad$ Real household net wealth per head ${ }^{1}$}

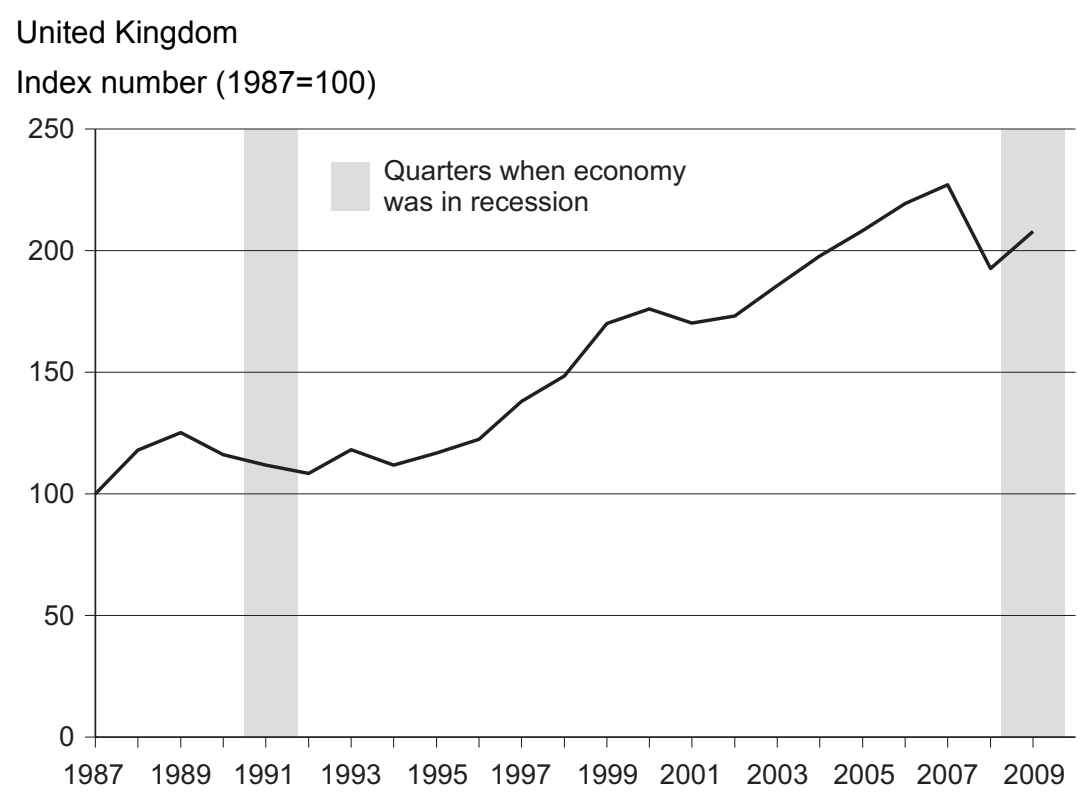

1 Adjusted to real terms using the expenditure deflator for the household sector.

Source: Office for National Statistics

Trends in the estimated total real household wealth per head in the UK between 1987 and 2009 are shown in Figure 6. In 2009 real household wealth was $£ 117,000$ per head, more than double that for $1987(£ 56,000)$ and an increase from the 2008 figure of $£ 109,000$. The real household wealth per head in 2008 was the lowest since 2003, reflecting the effects of the recession. 


\section{Figure 7 Distribution of household wealth including pension wealth: by earned income per week, ${ }^{1}$ 2006-08}

Great Britain

$£$ per week

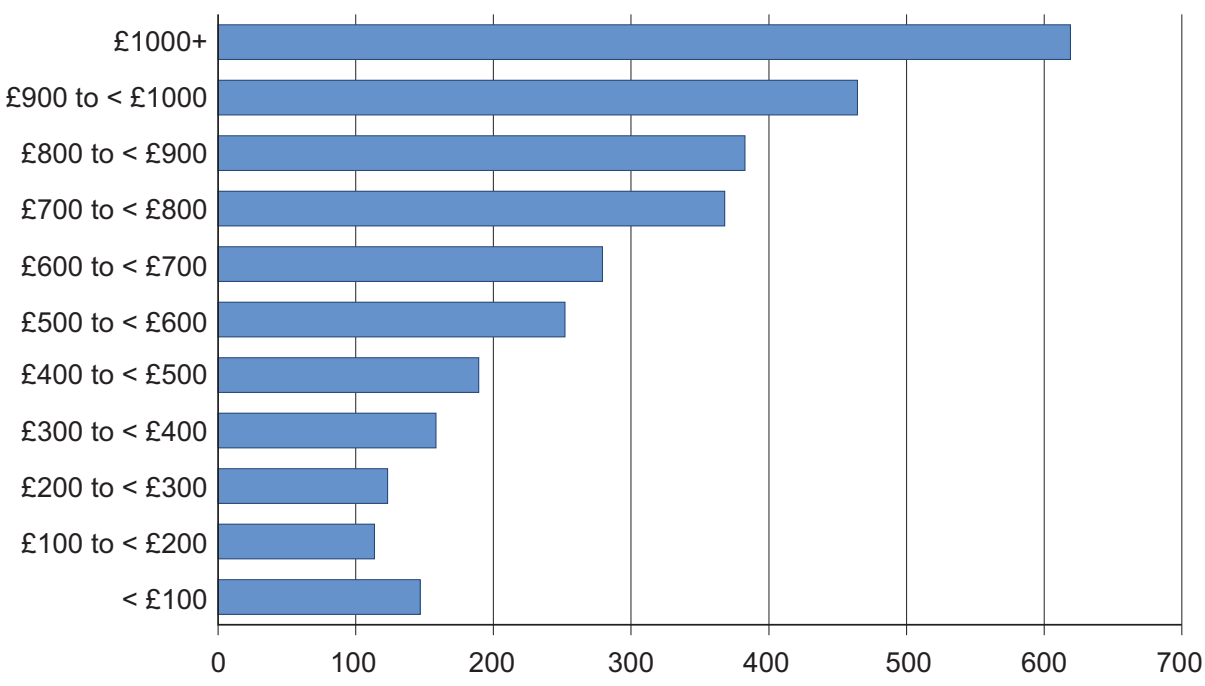

1 Earned income is income from employment and self-employment. It excludes income from pensions, benefits, and other sources such as interest and dividends.

Source: Wealth and Assets Survey, Office for National Statistics

The Wealth and Assets Survey collects information about earned income from employment and self-employment excluding any income from pensions, benefits and other sources. The analysis of total household wealth by grouped earned income for 2006 to 2008 is shown in Figure 7. As would be expected, higher total wealth is in general associated with the higher earned income bands. However, there is an exception for the lowest earned income band of less than $£ 100$, where median wealth is higher than those in the two income bands between $£ 100$ and less than $£ 300$. Those with very low earned incomes might well be expected to benefit from income from sources other than earnings such as benefits, pensions and investments. The total wealth of those in these groups may well fall into two categories: those who receive benefits and have very low levels of assets, and those who have wealth in the form of houses, pensions and investments from which they derive unearned income.

Ownership of wealth also varies between regions. In 2006/08 in Great Britain, median total household total wealth was lowest in Scotland $(£ 150,600)$ and highest in the South East (£287,900) (ONS, 2009b).

Wealth can be held in different forms. Financial wealth is composed of assets such as saving accounts, which may provide sources of current income, and those such as pension rights which may provide entitlement to a future income flow. Ownership of non-financial wealth, such as property, does not necessarily provide an income flow but may provide financial security. 


\section{Table 5 Composition of the net wealth ${ }^{1}$ of the household sector, 2009}

United Kingdom

$£$ Billion at 2009 prices $^{2}$

\begin{tabular}{|c|c|c|c|}
\hline & 2007 & 2008 & 2009 \\
\hline \multicolumn{4}{|l|}{ Non-financial assets } \\
\hline Residential buildings & 4,260 & 3,737 & 3,827 \\
\hline Other & 881 & 776 & 796 \\
\hline \multicolumn{4}{|l|}{ Financial assets } \\
\hline Life assurance and pension funds & 2,266 & 1,892 & 2,192 \\
\hline Securities and shares & 666 & 452 & 577 \\
\hline Currency and deposits & 1,153 & 1,189 & 1,184 \\
\hline Other assets & 173 & 197 & 199 \\
\hline Total assets & 9,399 & 8,243 & 8,776 \\
\hline \multicolumn{4}{|l|}{ Financial liabilities } \\
\hline Loans secured on dwellings & 1,233 & 1,240 & 1,235 \\
\hline Other loans & 230 & 230 & 209 \\
\hline Other liabilities & 128 & 103 & 87 \\
\hline Total liabilities & 1,591 & 1,573 & 1,531 \\
\hline Total net wealth & 7,807 & 6,670 & 7,244 \\
\hline
\end{tabular}

1 At end of each year.

2 Adjusted to 2009 prices using the expenditure deflator for the household sector.

Source: Office for National Statistics

The value of the stock of net wealth owned by a household equals the amount of accumulated assets (such as houses, pensions and life assurance) less liabilities (such as mortgages and other loans). In 2009 the total net wealth owned by the household sector in the UK was $£ 7.2$ trillion (Table 5). This was lower than 2007 but an increase relative to 2008. These changes are related to the effects of the recession in 2008-2009 on different parts of the UK economy. In the nonfinancial sector, house prices fell considerably between 2007 and 2008 but then began to recover in 2009 , and these changes are reflected in the asset value of residential buildings. In the financial sector, changes in stock market prices have reduced the value of securities and shares, life assurance and pension funds. Total financial liabilities were very similar in all three years: about 80 per cent of all liabilities were loans secured on dwellings in each year. 


\section{Table 6 Reason for not saving into a pension ${ }^{1}$ 2006-2008}

Great Britain

Percentages

Can't afford to contribute/low income/ not working/still in education 65

Not interested/ thought about it/got around to it

Prefer alternative forms of saving

Too many debts/bills/financial commitments

Don't know enough about pensions

Too early to start a pension

Don't trust pension companies/schemes

Not eligible/employer doesn't offer a pension scheme

Too late to start a pension

Not staying with employer/looking for a new job/recently changed jobs

Past pension arrangements are adequate

Don't think I will live that long

Employer scheme not attractive/generous

Other

Don't know (spontaneous only)

1 Individuals aged under 60 not paying into a pension and not receiving a pension.

Source: Wealth and Assets Survey, ONS (2009b)

Money set aside for future retirement is also an important form of household wealth, as it will affect a person's living standards in the future. Averaged over the period 2006 to 2008, 55 per cent of people under the age of 60 in Great Britain were neither saving for a pension nor already receiving income from one (ONS, 2009b). Nearly two-thirds attributed this to having a low income, being out of employment or being in education (Table 6). 


\section{Household savings}

The household saving ratio is defined as household saving as a percentage of total resources, comprising disposable income and the change in the net equity of households in pension funds. It is a key indicator of households' willingness and ability to purchase goods and services.

\section{Figure $8 \quad$ Household saving ratio ${ }^{1}$}

United Kingdom

Percentages

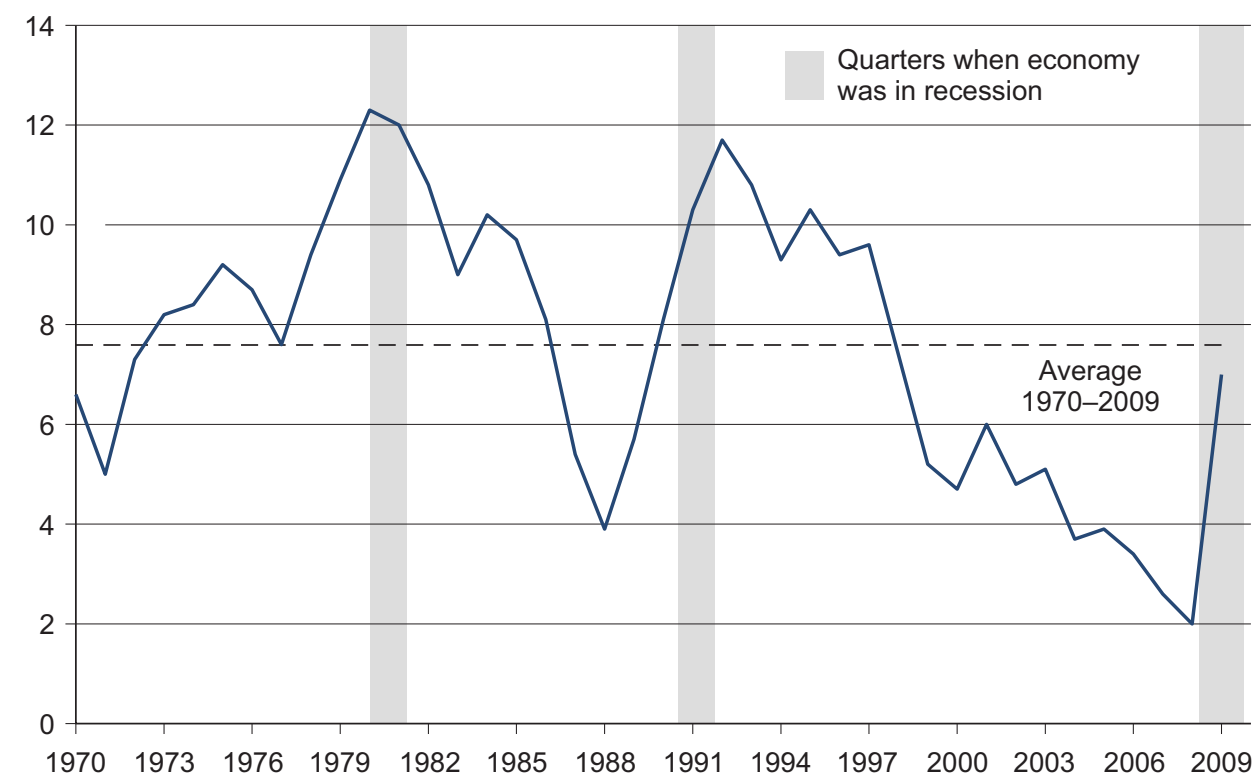

1 Household saving ratio is household saving expressed as a percentage of total resources.

Source: Office for National Statistics

In 2009 the household saving ratio was at a similar level to that in1998 (Figure 8). The household saving ratio peaked either during or soon after the recessions in the 1980s and 1990s, and appears to be following the same pattern in the most recent recession of 2008-09. The trend in household saving ratio since 1992 has been variable, but generally downwards from a peak of 11.7 per cent to a low point of 2.0 per cent in 2008. However, there was an increase in 2009 to 7.0 per cent which reflected the effects of the most recent recession. 


\section{Taxes}

Taxes are the main means by which governments raise revenue. In earlier centuries tax liabilities were typically based on a variety of measures of the value of property. Taxes on income were first raised in Great Britain by William Pitt the Younger ${ }^{\mathrm{vii}}$ in the 1790s to finance the Napoleonic Wars. Today the major taxes paid by individuals are income tax, social contributions and taxes on expenditure. The income tax system in the UK is progressive, meaning that people with higher incomes are subject to higher rates of tax and so pay higher proportions of their income in taxes.

\section{Table $7 \quad$ Income tax payable: ${ }^{1}$ by annual income, ${ }^{2}$ 2010/11}

United Kingdom

\begin{tabular}{|c|c|c|c|c|}
\hline & $\begin{array}{r}\text { Number of } \\
\text { taxpayers } \\
\text { (thousands) }\end{array}$ & $\begin{array}{l}\text { Total tax liability after tax } \\
\text { reductions }{ }^{3} \text { ( } £ \text { million) }\end{array}$ & $\begin{array}{r}\text { Average rate of tax } \\
\text { (percentages) }\end{array}$ & $\begin{array}{r}\text { Average } \\
\text { amount of tax } \\
(£)\end{array}$ \\
\hline$£ 6,475-£ 7,499$ & 939 & 86 & 1.3 & 91 \\
\hline$£ 7,500-£ 9,999$ & 2,620 & 1,000 & 4.3 & 382 \\
\hline$£ 10,000-£ 14,999$ & 6,440 & 6,150 & 7.7 & 956 \\
\hline$£ 15,000-£ 19,999$ & 5,210 & 10,200 & 11.3 & 1,960 \\
\hline$£ 20,000-£ 29,999$ & 6,910 & 23,100 & 13.7 & 3,350 \\
\hline$£ 30,000-£ 49,999$ & 5,680 & 33,000 & 15.4 & 5,800 \\
\hline$£ 50,000-£ 99,999$ & 2,050 & 30,000 & 22.3 & 14,600 \\
\hline$£ 100,000-£ 149,999$ & 342 & 12,200 & 29.8 & 35,700 \\
\hline$£ 150,000-£ 199,000$ & 145 & 8,120 & 33.1 & 55,900 \\
\hline$£ 200,000-£ 499,999$ & 143 & 15,500 & 37.8 & 109,000 \\
\hline$£ 500,000-£ 999,999$ & 26 & 7,340 & 41.4 & 281,000 \\
\hline$£ 1,000,000$ and over & 13 & 12,700 & 44.4 & $1,010,000$ \\
\hline All incomes & 30,500 & 159,000 & 18.3 & 5,220 \\
\hline
\end{tabular}

1 Based on projections in line with the March 2010 Budget and subsequent changes (June 2010) to the income tax personal allowance and basic rate limit.

2 Total income of the individual for income tax purposes including earned and investment income. Figures relate to taxpayers only.

3 In this context tax reductions refer to allowances given at a fixed rate, for example the married couple's allowance.

Source: HMRC (2010)

For $2010 / 11$ the personal allowance (below which no tax is payable) is $£ 6,475$ and there are three rates of income tax: taxable income up to $£ 37,400$ charged at 20 per cent, between $£ 37,401$ and $£ 150,000$ charged at 40 per cent, and over $£ 150,000$ charged at 50 per cent. Taking into account the personal allowance and any other tax relief to which an individual may be entitled, and the variable rates of taxation, the estimated actual proportion of income payable as tax varies by income group (Table 7). The average tax rate projected for 2010/11 was 18.3 per cent. This 
compares with the projected rate of 1.3 per cent for those with earnings between $£ 6,475$ and $£ 7,499$ and 44.4 per cent per cent for those with earnings of over $£ 1$ million (HMRC, 2010). The average amount payable during the year also varies considerably, from $£ 91$ for individuals earning between $£ 6,475$ and $£ 7,499$, to $£ 1.01$ million for those earning over $£ 1$ million.

\section{Table $8 \quad$ Indirect taxes as a percentage of disposable income: by expenditure $^{1}$ and income ${ }^{2}$ grouping of households, 2008/09}

United Kingdom

Percentages

Expenditure distribution

\section{Bottom fifth}

Second fifth

Middle fifth

Fourth fifth

Top fifth
12.3

15.8

17.2

16.8

18.2

16.7
Income distribution

16.8

12.8

All households

16.7

1 Households are ranked by equivalised expenditure.

2 Households are ranked by equivalised income.

Source: Office for National Statistics

Indirect taxes are those such as VAT, duties, and levies which are paid on the purchase of goods and services. Overall, indirect taxes amounted to 16.7 per cent of disposable household income in 2008/09. The amount of indirect tax that each household pays is determined by their expenditure rather than their income. Therefore it is useful to study their effects on household material living standards, referring to both the distribution of household income and household expenditure. As would be expected, when households are ranked and grouped based on their level of expenditure, indirect taxes constitute a lower proportion of income for those with expenditure in the bottom fifth of all expenditure than for those in the top fifth (12.3 per cent and 18.2 per cent respectively). Therefore indirect taxes can be regarded as progressive with respect to expenditure; that is the more you spend, the higher the proportion paid in indirect taxes (Table 8).

When analysed (by ranking households based on their income rather than expenditure) indirect taxes represent a higher proportion of income for those households with incomes in the bottom fifth of all incomes when compared to households in the highest fifth (28.2 per cent and 12.8 per cent respectively). This is because, although households in lower income groups spend smaller amounts, the indirect taxes paid make up a higher percentage of their income. Therefore indirect taxes can be regarded as regressive with respect to income; that is the less you earn, the higher the proportion you pay in indirect taxes. Indirect taxation forms a larger percentage of the income of lower income households, even though they may also spend less. 


\section{References}

Chiripanhura (2010). Measures of economic activity and their implications for societal wellbeing. Available at www.statistics.gov.uk/elmr/07 10/downloads/ELMR Jul10.pdf

DWP (2010a). Family Resources Survey: United Kingdom 2008-09. Available at http://statistics.dwp.gov.uk/asd/frs/2008 09/index.php?page=intro

DWP (2010b). Households Below Average Income: An analysis of the income distribution 1994/95-2008/09. Available at http://statistics.dwp.gov.uk/asd/hbai/hbai 2009/index.php?page=contents

HMRC (2010). Table 2.5: Income tax liabilities, by income range. Available at www.hmrc.gov.uk/stats/income tax/menu.htm

Oguz and Knight (2010) Regional Economic indicators with a focus on gross disposable household income Available at www.statistics.gov.uk/elmr/05 10/downloads/ELMR-May10-Knight.pdf

ONS (2009a). ST40: Population. Available at www.statistics.gov.uk/cci/nugget.asp?id=2311

ONS (2009b). Wealth in Great Britain: Main Results from the Wealth and Assets Survey 2006/08. Available at www.statistics.gov.uk/StatBase/Product.asp?vlnk=15074\&Pos=1\&ColRank=1\&Rank=192

ONS (2009c). 2009 Annual Survey of Hours and Earnings (ASHE): Analysis by All Employees. Available at www.statistics.gov.uk/downloads/theme labour/ASHE-2009/2009 all employees.pdf 


\section{Notes}

i The household sector covers people living in households and institutions and also sole traders, and charities and universities. Disposable income is the amount of money that households have available for consumption expenditure or savings and is calculated by taking total income from all sources and deducting expenditure on taxes, social contributions and other expenses such as insurance premiums.

ii The household reference person is the person responsible for the accommodation, be it through ownership, renting, having the accommodation as part of a job or a relationship to an owner who is not part of the household. For joint householders, the reference person is taken to be the one with the highest income or, if their income is equal, the oldest person.

iii The analysis in Households Below Average Income (HBAI) uses household disposable incomes, adjusted for household size and composition, as a proxy for the material living standards of individuals or, more precisely, for the level of consumption of goods and services that people could attain given the disposable income of the household in which they live. This is known as equivalisation and allows the comparison of incomes between households of different sizes and compositions.

iv Nomenclature of Units for Territorial Statistics (NUTS) is a hierarchical classification of areas that provides a breakdown of the EU's economic territory. For further information go to www.statistics.gov.uk/geography/nuts.asp

v The Consumer Price Index (CPI) is the main UK measure of inflation for macroeconomic purposes and forms the basis for the Government's inflation target. It is also used for international comparisons. The CPI is the measure adopted by the Government for monitoring inflation and indexing benefits and tax credits.

vi The Retail Prices Index (RPI) is the most familiar general purpose domestic measure of inflation in the UK. It is available continuously from June 1947. Until 2010 the government used it to uprate state pensions, social security benefits and index-linked gilts.

vii In his budget of December 1798 William Pitt introduced a new graduated income tax. Beginning with a 120th tax on incomes of $£ 60$ and rising by degrees until it reached 10 per cent on incomes of over $£ 200$. Pitt believed that this income tax would raise $£ 10$ million but in fact in 1799 the yield was just over $£ 6$ million. 